\title{
Vagococcus salmoninarum, a bacterium of pathological significance in rainbow trout Oncorhynchus mykiss farming
}

\author{
C. Michel ${ }^{1, *}$, P. Nougayrède ${ }^{2}$, A. Eldar ${ }^{3}$, E. Sochon ${ }^{4}$, P. de Kinkelin ${ }^{1}$ \\ ${ }^{1}$ Unité de Virologie et d'Immunologie Moléculaires, INRA-CRJJ, Domaine de Vilvert, F-78352 Jouy-en-Josas cedex, France \\ ${ }^{2}$ Services vétérinaires, 120 av. Pasteur, F-40010 Mont-de-Marsan cedex, France \\ ${ }^{3}$ Fish Diseases Laboratory, Kimron Veterinary Institute, POB 12, Beit Dagan 50250, Israel \\ ${ }^{4}$ Pisciculture Estalens, F-32110 Nogaro, France
}

\begin{abstract}
A chronic condition of juvenile and adult rainbow trout was recorded in a trout farm over several years and resulted in significant mortality. The disease occurred mainly at low temperature. Necropsy findings were associated with hyperaemia and haemorrhage, in gills and viscera, with extensive cardiovascular lesions including myocarditis and epicarditis. Most of the losses were attributed to heart lesions and mortality peaked under stress conditions. A Gram-positive, chain-forming, coccoid to ovoid-shaped coccus identified as Vagococcus salmoninarum on the basis of phenotypic and genetic characteristics was regularly isolated from diseased fish. It was demonstrated to be the causative agent of the condition by infection experiments and histopathology, which also confirmed the affinity of the bacterium for the circulatory system. $V$. salmoninarum was resistant to most of the antimicrobial drugs tested in vitro, and the treatments conducted in the field were ineffective. An attempt at vaccination did not provide encouraging results. $V$. salmoninarum joins a list of Gram-positive bacteria responsible for chronic infections which do not respond to control procedures and which pose a serious threat to broodstock and large-sized fish.
\end{abstract}

KEY WORDS: Vagococcus salmoninarum - Rainbow trout - Gram-positive bacteria - Natural infection Experimental disease $\cdot$ Histopathology

\section{INTRODUCTION}

With the exception of Renibacterium salmoninarum and several species of mycobacteria, fish infections caused by Gram-positive bacteria were not frequently reported until the middle of the seventies. The development of intensive farming in marine and freshwater environments led to an increasing number of clinical cases in which lactic acid producing bacteria such as streptococci and lactobacilli were involved.

Streptococcosis and related infections occur in many species of fish in Japan and in other countries (Austin \& Austin 1987, Kitao 1993). Many isolates have been reported, and although their accurate identification often remained impossible, the creation of new species

•E-mail: michel@biotec.jouy.inra.fr was proposed to accommodate some of them. These include Streptococcus iniae (Pier \& Madin 1976), initially isolated from Amazonian freshwater dolphins Inia geoffrensis, and pathogenic strains isolated from the tilapia Oreochromis sp. in Israel, for which the species Streptococcus difficile was created (Eldar et al. 1994). Many of the isolates formerly depicted in Japan, Taiwan and the USA could be ultimately ascribed to one of these species (Eldar et al. 1995). Other agents reported as pathogenic to fish have already been described from different sources. 'Enterococcus seriolicida' (Kusuda et al. 1991), an $\alpha$-haemolytic agent responsible for high losses in farming of the Japanese yellowtail Seriola quinqueradiata and other marine fish, has been recently reassigned to Lactococcus garvieae (Eldar et al. 1996). While related forms were recorded in Europe, affecting turbot Scophthalmus maximus (Toranzo et al. 1994), rainbow trout Onco- 
rhynchus mykiss (Ghittino \& Prearo 1992) and sturgeon Acipenser naccarii (Salati et al. 1996), some of the turbot isolates were identified as Streptococcus parauberis (Doménech et al. 1996).

Chronic conditions associated with rod-shaped lactic-acid bacteria have been demonstrated to occur in several freshwater species, including salmonids physiologically weakened during sexual maturation. The first example was the pseudo kidney disease caused by Carnobacterium piscicola (formerly Lactobacillus piscicola), which was recognized by Ross \& Toth (1974) and suspected of having been occasionally confused with Renibacterium salmoninarum. C. piscicola is an ubiquitous and probably opportunistic bacterium which was isolated in other geographical areas as well. A comprehensive study resulted in the description of 2 other related cocci bacteria, apparently able to survive in and potentially infect the salmonids Lactococcus piscium (Williams et al. 1990) and Vagococcus salmoninarum (Wallbanks et al. 1990).

There were no more reports of Vagococcus salmoninarum from rainbow trout, so it was assumed the bacterium combined low prevalence with limited pathogenicity. However, Schmidtke \& Carson (1994) noted isolates from different geographical sources, although little was specified about their pathogenic properties. In 1993, heavy mortality due to a Grampositive bacterium was recorded in a trout farm in the southwest of France. Subsequently, similar mortality occurred every year. This paper identifies the responsible agent as $V$. salmoninarum and provides some clinical data that should contribute towards an assessment of the pathogenic nature of this bacterium.

\section{MATERIAL AND METHODS}

The farm. Rainbow trout mortality occurred at a farm supplied with spring water at a constant temperature of 9 to $10^{\circ} \mathrm{C}$. The farm was registered in an official fish health control system and was regularly monitored. Other bacterial infections were rarely diagnosed, and the bacterial kidney disease agent was not detected. Treatments combining or alternating formalin and malachite green were performed weekly to limit ectoparasites and mycotic agents.

Clinical and microscopical observation. Rainbow trout from affected groups were examined for external and internal lesions. Tissues of moribund fish undergoing both natural infection ( 7 fish) and experimental challenge ( $3 \mathrm{fish}$ ) were fixed in $10 \%$ formalin and processed for histopathology using standard techniques. Histological sampling encompassed eye, encephalon, gill, ulcerated skin, heart, liver, spleen, stomach and intestine. The sections were stained with haematoxylin- eosin-safranin, Giemsa and Gram stain. All 10 fish sampled presented congestive clinical signs, and 7 of them had flank ulcers and unilateral exophthalmia.

Bacteriological study. Material obtained from kidney, spleen, liver, or other affected organs was streaked onto trypticase-soy-agar (TSA) or Columbia agar with $10 \%$ defibrinated sheep blood (Diagnostic Pasteur, France) and incubated $48 \mathrm{~h}$ at $22^{\circ} \mathrm{C}$. Isolated colonies were resuspended in physiological saline to carry out biochemical characterization and antimicrobial tests. Gram staining, motility, oxidase and catalase reactions, nitrate reduction and growth at different temperatures, at different salt concentrations, or in $40 \%$ bile, were studied using reagents and media from Diagnostic Pasteur (France). Hydrogen sulphide production was tested both in commercial Kligler-Hajna (glucose-lactose- $\mathrm{H}_{2} \mathrm{~S}$ ) medium and TSA medium containing agar $4 \mathrm{~g} \mathrm{l}^{-1}$, sodium thiosulphate $1 \mathrm{~g} \mathrm{l}^{-1}$, and lead hydroxyde-acetate $2 \mathrm{~g} \mathrm{l}^{-1}$. Additional tests were performed using the API 20 NE, API 20 STREP and API 50 CHL systems (Rhône-Mérieux, France).

Antimicrobial tests were conducted at $22^{\circ} \mathrm{C}$ by the diffusion method, using Mueller-Hinton medium and discs purchased from Diagnostic Pasteur. Incubation was prolonged for $48 \mathrm{~h}$.

DNA relatedness. The methods used to produce and lyse streptococci and to extract their DNA have been described (Eldar et al. 1994). Briefly, the pellets obtained from growth in $1 \mathrm{l}$ brain-heart-infusion (BHI, Difco) were lysed using lysozyme (Sigma) $2 \mathrm{mg} \mathrm{ml}^{-1}$, mutanolysin (Sigma) 5 units $\mathrm{ml}^{-1}$, sodium dodecyl sulphate (SDS) $0.5 \%$, and pronase $\mathrm{E}$ (Sigma) $10 \mathrm{mg} \mathrm{ml}^{-1}$. The DNA was purified by phenol/chloroform extractions and stored at $4^{\circ} \mathrm{C}$ until use. Three reference strains from the National Collection of Food Bacteria (Reading, UK) were compared to the trout isolates: Vagococcus salmoninarum NCFB $2777^{\mathrm{T}}$, Lactococcus piscium NCFB $2778^{\top}$ and Lactococcus lactis NCFB $604^{\top}$.

DNA-DNA hybridization was carried out as described (Eldar et al. 1994), with modifications regarding the volumes employed. In a final volume of $100 \mu l_{\text {, }}$ $15 \mu \mathrm{g}$ of sonicated DNA was hybridized with $5 \mathrm{ng}$ of nick-translated (Amersham) ${ }^{32}$ P-labeled DNA (30 000 to $50000 \mathrm{cpm}$. After boiling, the reassociation of single-stranded DNAs was allowed to proceed at $60^{\circ} \mathrm{C}$. Single and double-stranded DNAs were separated by the hydroxyapatite (DNA grade, Bio-Rad) method (Brenner et al. 1969). Reactions were carried out in duplicate, and each run performed twice. Relative Binding Ratio (RBR) and the differences in melting points $\Delta T_{\text {minel }}$ reflecting the divergence in related DNA sequences were calculated according to Brenner et al. (1969). The rate of reassociation of the labeled DNA (4 to $5 \%$ ) was subtracted from the absolute ratios of the hybridization. 
Experimental infections. The experimental facilities were supplied by well water with constant $\mathrm{pH}(\mathrm{pH}=7)$ and temperature $\left(14^{\circ} \mathrm{C}\right)$. Three experiments were conducted, by intraperitoneal (IP) injection, intramuscular (IM) injection and immersion in a bacterial supension, using groups of rainbow trout originating from a 'Vagococcus-free' farm and averaging 300, 70 and $10 \mathrm{~g}$ respectively. Bacterial cultures were prepared from a single strain (119-94) which had been frozen at $-80^{\circ} \mathrm{C}$ immediately after isolation from fish. The bacteria were grown in 21 trypticase soy broth (TSB) erlenmeyer flasks stirred at $20^{\circ} \mathrm{C}$ for 48 or $72 \mathrm{~h}$, before being diluted to prepare infective suspensions (see Table 4) and perform plate enumeration. The mortality was recorded for periods of 4 to 5 mo. All moribund and freshly dead fish were examined and processed for microbiological testing, and in some cases moribund fish were sampled for histopathology.

Vaccination trial. Farmed rainbow trout of $1200 \mathrm{~g}$ were immunised intraperitoneally. Vagococcus salmoninarum 119-94 cultivated $48 \mathrm{~h}$ at $20^{\circ} \mathrm{C}$ in an $8 \mathrm{l} \mathrm{TSB}$ fermenter and inactivated with $1 \%$ formalin was used as the bacterin. Individual doses contained approximately $2.5 \times 10^{10}$ bacteria in $0.5 \mathrm{ml}$. After $7 \mathrm{mo}$, equal groups of 40 immunized or control fish were transported to the experimental facilities, acclimatized at $14^{\circ} \mathrm{C}$, and challenged with an IM injection of $2 \times 10^{8}$ colony-forming units (cfu). The resulting mortality was recorded over a period of $2 \mathrm{mo}$.

\section{RESULTS}

\section{Clinical observations}

Mortality occurred in farmed rainbow trout in 1993 and, in spite of repeated antimicrobial treatments (using tetracyclines, sulphonamides associated with trimethoprim, nitrofurans, amino-penicillins or macrolides), persisted with only a single break in summer 1994. Losses reached $50 \%$ in one year, from spring 1993 to spring 1994. Adult trout from 600 to $4000 \mathrm{~g}$ were the most susceptible, with peaks of mortality rising subsequent to handling (sorting, striping) or other stress factors. In autumn 1994, for instance, the disease reappeared just after a natural flood.

Diseased trout were listless and exhibited clinical signs generally associated with a bacterial septicaemia, including marked loss of equilibrium and swimming difficulty. External haemorrhage was observed in the ocular area (Fig. 1c) and in certain cases unilateral exophthalmia. Errosive lesions, when present, developed on the body sides and the opercula surface. Internal lesions consisted of discoloration and petechial haemorrhages of gills, enlargement and con- gestion of the spleen and liver (although in some cases the liver appeared pale) with disseminated foci of congestion. The digestive tract was empty, and gastritis was noticed in some fish. In the advanced stages, a fibrinous exudate occurred in the peritoneal and pericardiac cavity, and heart lesions consisting of epicarditis were found (Fig. 1a, b).

\section{Histopathology}

The histopathological examination substantiated the findings recorded at necropsy. Hyperaemia and oedema were present in most tissues. The major pathological feature was an epicarditis that occurred in natural and experimental infections (Fig. 2). The epicardium was thickened in natural infection (Fig. 2) and harboured numerous Gram-positive cocci among dilated blood capillaries, mononuclear cells and fibrinous tissue. The underlaying cortical layer of ventricular myocardium was infiltrated by hyperhaemic bacteria-harbouring capillaries, resulting in loss of homogeneity of this layer as seen in experimental infection (Fig. 3). Gram-positive bacteria were present in dilated capillaries, and foci of bacterial growth on muscular fibers were observed early in degenerative changes. The hyperhaemic response in endocardium was especially marked following experimental infection because the fish were sampled before the chronic stage of disease was reached (Fig. 4).

Septicaemia was assessed by the presence of Grampositive bacteria in the blood capillaries from the white matter of optic lobes of encephalon, liver and kidney (not shown). Furthermore, moderate meningitis was recorded in 3 fish (not shown), which stresses the affinity of Vagococcus salmoninarum for trout serosae.

The tegumentary lesions were due to intensive macrophage and lymphocyte infiltration of epidermis, dermis, hypodermis and underlying muscular layers (Fig. 5). No bacteria were revealed by Giemsa or Gram staining, but the above inflammatory response resulted in the thickening of skin and numerous degenerative features leading to the disruption of epidermis which can substantiate the errosive skin lesions observed clinically (Fig. 5).

Exophthalmos was due to retrobulbar accumulation of haemorrhagic exudate, but again no bacteria could be seen. Other than hyperaemia no splenic changes were observed.

\section{Bacteriology}

The same organism was regularly isolated from all the affected tissues of fish submitted for bacteriological 

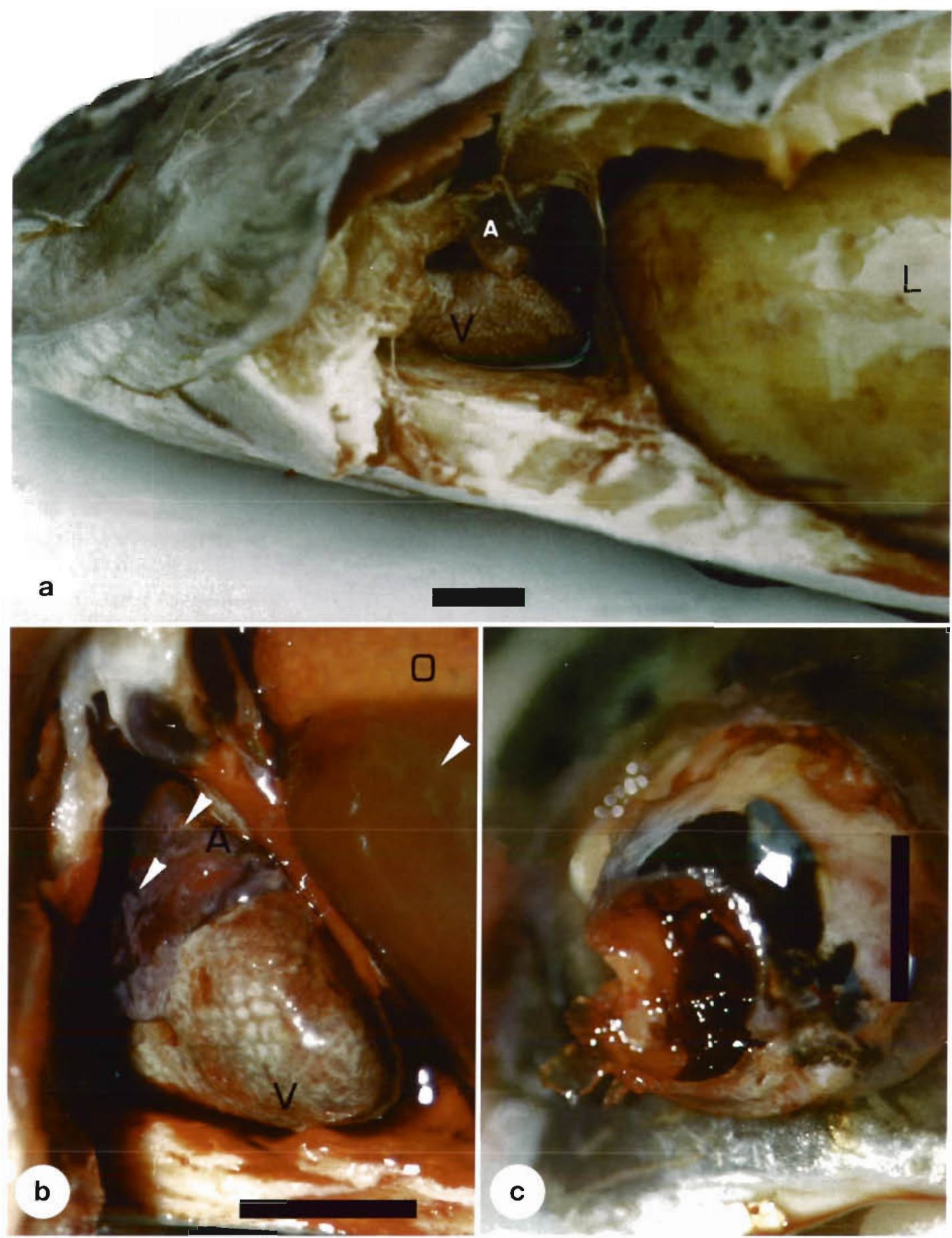

Fig. 1. Vagococcus salmoninarum naturally infected Oncorhynchus mykiss. (a) 4 yr old fish exhibiting epicarditis (V: ventricle; A: atrium) and peritonitis appearing as fibrinous deposit on liver (L). Scale bar $=10 \mathrm{~mm}$. (b) Close-up of cardiac lesions in brood fish: miliary-shaped epicarditis on ventricle (V). diffuse reaction on atrium and faint fibrinous deposit on liver (arrowheads). O: ovary. Scale bar $=10 \mathrm{~mm}$. (c) Unilateral exophthalmia and lens enucleation. Scale bar $=10 \mathrm{~mm}$

investigation, indicating a systemic condition. After $48 \mathrm{~h}$ the culture was abundant, growing slightly better on blood agar than on TSA, and formed small, white, smooth colonies, 0.5 to $1 \mathrm{~mm}$ in diameter. Gram-stained smears displayed thick coccoid to ovoid-shaped Grampositive bacteria, which usually appeared as diplococci in infected tissues but which were able to form chains of variable length after growing in liquid medium. On 

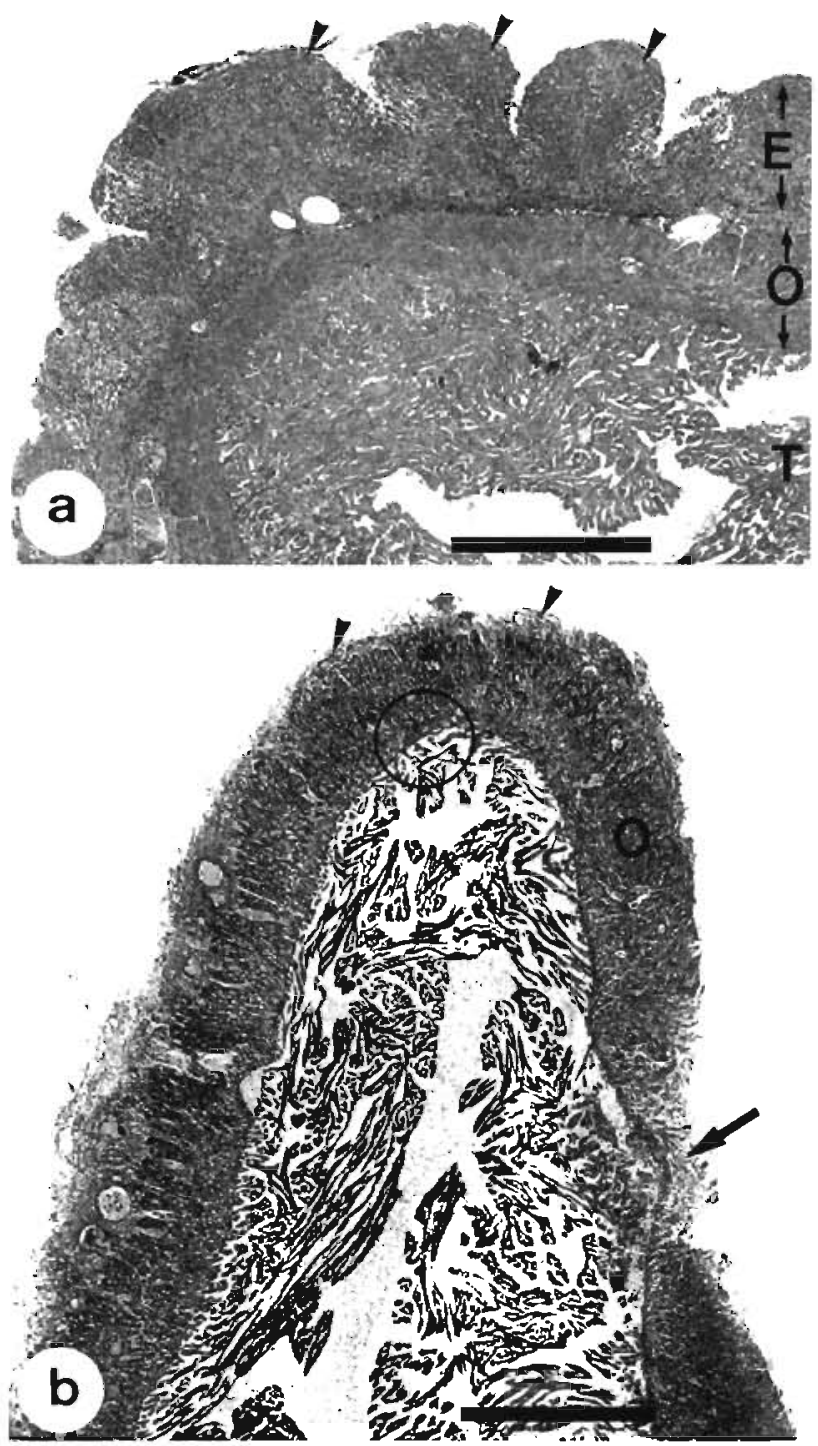

Fig. 2. Oncorhynchus mykiss. Histological lesions of ventricle in Vagococcus salmoninarum infection. Giemsa stain. Scale bar $=1 \mathrm{~mm}$. (a) Ventricle from the fish shown in Fig. 1b: marked thickening of epicardium (E), miliary lesions of which appear club-shaped on section (arrowheads). O: compact outer myocardium; T: trabecular layer. (b) Sagitally sectioned ventricle from a $1 \mathrm{yr}$ old rainbow trout intraperitoneally injected with $1 \times 10^{7} \mathrm{~V}$. salmoninarum: thin epicarditis (arrowheads) and hyperaemia in outer myocardium layer associated with a weakened area leading to cardiac wall disruption (arrow). Close-ups of circled areas are featured in Figs. $3 \& 4$

blood Columbia agar, limited $\alpha$-haemolysis was produced after 2 to $3 \mathrm{~d}$. This facultative anaerobic bacterium was non-motile, asporogenous, did not produce oxidase or catalase and seemed to be related to lacticacid bacteria, and even more closely to streptococci or enterococci. Further characteristics are listed in Table 1. In API 20-STREP systems the most common numerical profile was 7162211

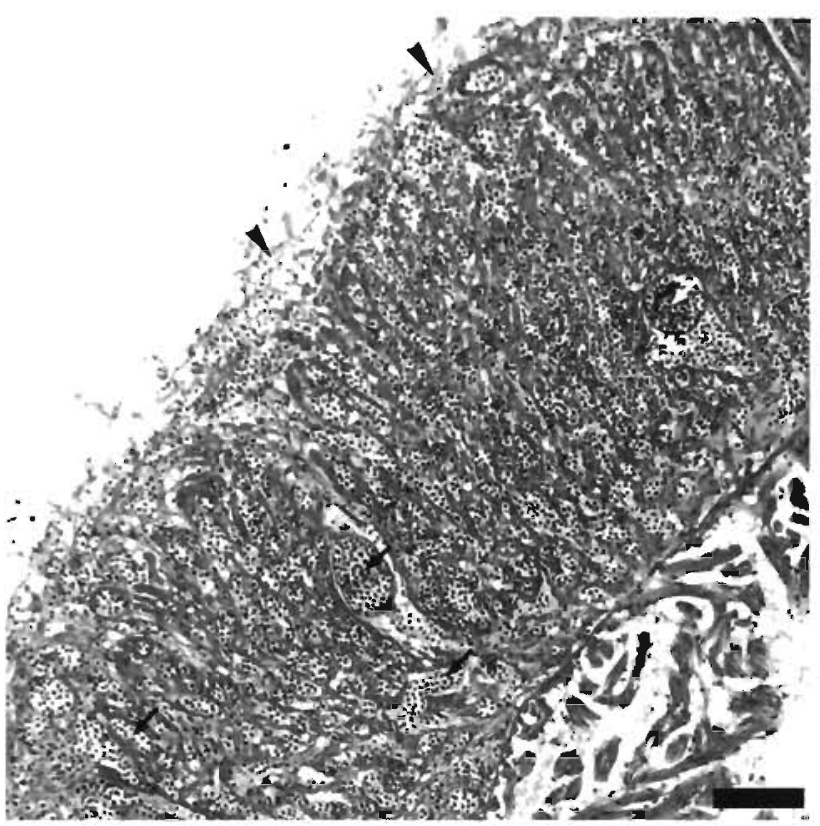

Fig. 3. Oncorhynchus mykiss. Experimental Vagococcus salmoninarum infection: moderate epicarditis (arrowheads), severe vascular dilation (arrows) separating muscular fibers in the myocardium (circled in Fig. 2b). Giemsa stain. Scale bar $=100 \mu \mathrm{m}$

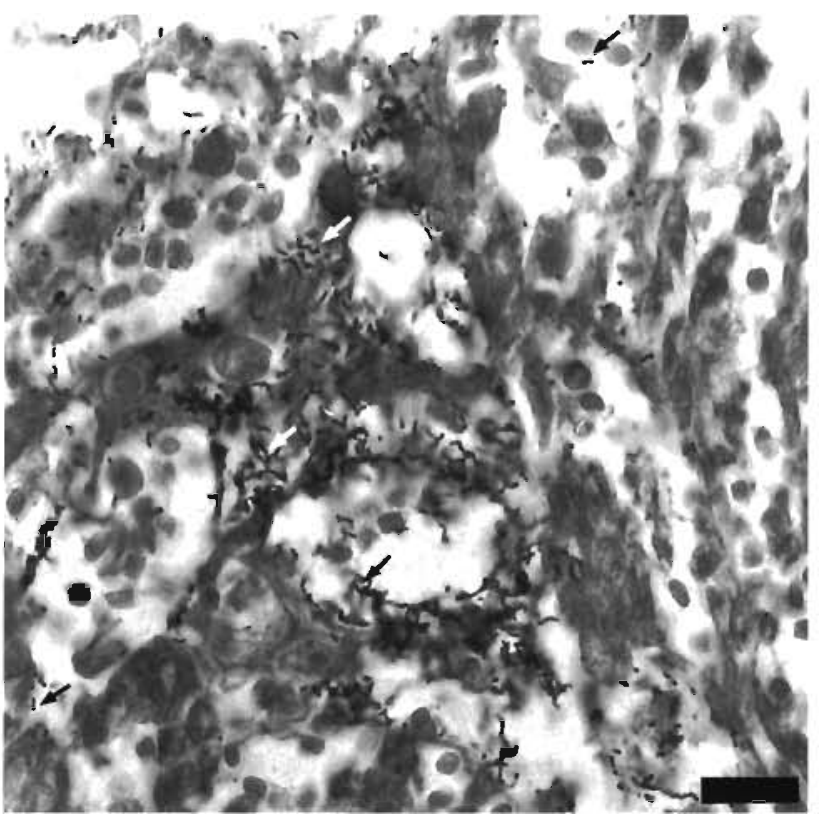

Fig. 4. Oncorhynchus mykiss. Chains of Vagococcus salmoninarum (arrows) proliferating on muscular fibres in the weakened area of ventricle arrowed in Fig. 2b. Gram staining Scale bar $=30 \mu \mathrm{m}$

Table 2 summarizes the differential characteristics of some salmonid-associated Gram-positive bacteria. A comparative analysis allowed us to assign our 


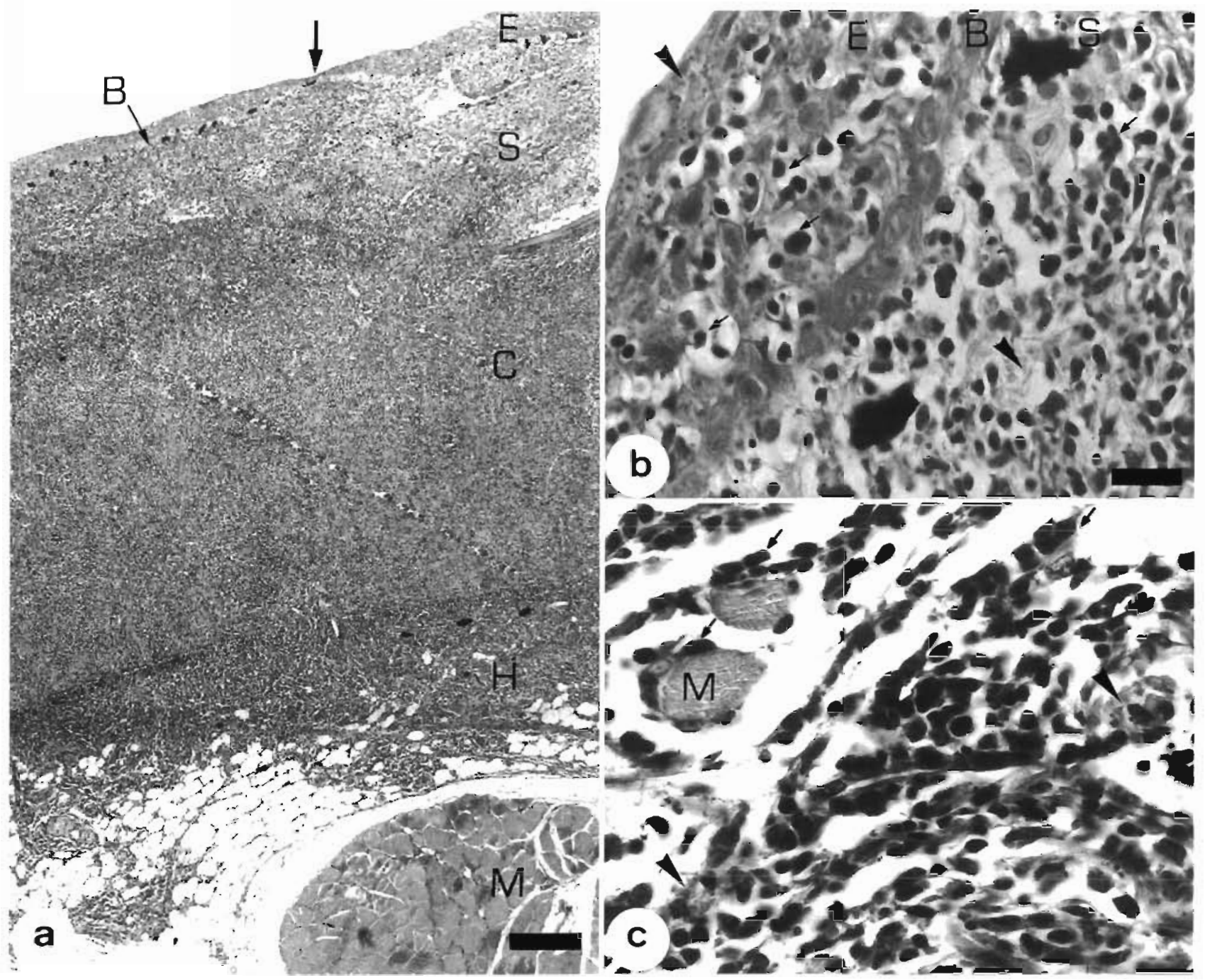

Fig. 5. Oncorhynchus mykiss. Tegumentary lesions associated with Vagococcus salmoninarum infection. (a) Acute tegumentary inflammation during natural infection. Severe cellular infiltration of all skin layers and hyperaemia in dermis and epidermis. The large arrow indicates a decrease in thickness of the epidermis featuring further erosive lesions observed clinically. B: basal layer; E: epidermis; S: stratum spongiosum; C: stratum compactum; $\mathrm{H}$ : hypodermis; M: muscle. H\&E safranin stain. Scale bar $=250 \mu m$ (b) Infiltration of epidermis and dermis by lymphocytes and macrophages (arrows); arrowheads: necrotic areas. Giemsa stain

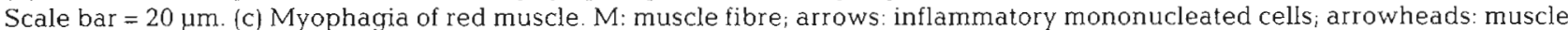
debris. Giemsa stain. Scale bar $=20 \mu \mathrm{m}$

strains to Vagococcus salmoninarum. This conclusion was supported by DNA hybridization, which demonstrated a high DNA relatedness and low $\Delta T_{\mathrm{m}(\mathrm{e})}$. The 6 tested isolates form a tight genomic group with the type strain $V$. salmoninarum NCFB $2777^{\top}$ (Table 3 ). Although $37^{\circ} \mathrm{C}$ was not an optimum temperature for the bacteria and routine antimicrobial tests could not be performed to accepted standards, a cautious interpretation indicated strong resistance to several drugs including oxacillin, streptomycin, sulphonamides, quinolones, and to a lesser degree neomycin and erythomycin.

\section{Experimental infection}

The mortality recorded after infecting trout by different routes is shown in Table 4. Only parenteral inoculation produced a chronic form of infection, which was more pronounced after IM injection than after IP injection. Dead fish exhibited the lesions commonly seen in natural disease, namely exophthalmia, abscesses or 'furuncles', congested visceral organs and heart. The bacteria could be reisolated in all cases, except from 4 out of 8 trout, the death which may be attributed to an interruption in the water supply. Mor- 
Table 1. Biochemical characteristics of Vagococcus salmoninarum, from 8 trout isolates studied in API 20 STREP and API 50 CHL systems and conventional tests. ADH: arginine-dihydrolase; VP: Voges-Proskauer; PYR: pyrrolidonyl-arrylamidase; PNPG: para-nitrophenyl-galactosidase; +: positive: -: negative; |+|: delayed or weak; d: variable character (number of positive strains in brackets)

\begin{tabular}{|c|c|c|c|c|c|}
\hline Tested & Result & Tested & Result & Tested & Result \\
\hline $\mathrm{ADH}$ & - & Glycerol & - & Salicin & + \\
\hline $\mathrm{NO}_{3}$ reduction & - & Erythritol & - & Cellobiose & $d(5)$ \\
\hline Hippurate & + & D-Arabinose & - & Maltose & $d(6)$ \\
\hline$V P^{x}$ & + & L-Arabinose & - & Lactose & - \\
\hline Urease & - & Ribose & $d(5)$ & Melibiose & - \\
\hline Indole & - & D-Xylose & {$[+]$} & Sucrose & + \\
\hline PYR & + & L-Xylose & - & Trehalose & + \\
\hline PNPG & + & Arabinol & - & Inulin & - \\
\hline Gelatinase & - & $\beta$-Methyl-xyloside & - & Melezitose & - \\
\hline \multirow{2}{*}{\multicolumn{2}{|c|}{$\mathrm{H}_{2} \mathrm{~S}$ ( $\mathrm{Pb}$ acetate medium) }} & Galactose & - & D-Raffinose & - \\
\hline & & D-Glucose & + & Starch & - \\
\hline Growth in: & & D-Fructose & + & Glycogen & - \\
\hline Bile $40 \%$ & + & D-Mannose & + & Xylitol & - \\
\hline Acetate medium & - & L-Sorbose & $d(7)$ & $\beta$-Gentiobiose & $d(4)$ \\
\hline \multirow[t]{2}{*}{$\mathrm{NaCl} 6.5 \%$} & - & Rhamnose & - & D-Turanose & - \\
\hline & & Dulcitol & - & D-Lyxose & - \\
\hline Growth at: & & Inositol & _- & D-Tagatose & + \\
\hline $40^{\circ} \mathrm{C}$ & - & Mannitol & - & D-Fucose & - \\
\hline \multirow{2}{*}{$37^{\circ} \mathrm{C}$} & $d(5)$ & Sorbitol & $d(6)$ & L-Fucose & $d(5)$ \\
\hline & & $\alpha$-Methyl-D-mannoside & - & D-Arabitol & - \\
\hline$\alpha$-Galactosidase & - & $\alpha$-Methyl-D-glucoside & - & L-Arabitol & - \\
\hline$\beta$-Galactosidase & - & N-Acetyl-glucosamine & + & Gluconate & - \\
\hline$\beta$-Glucuronidase & - & Amygdalin & + & 2-Ketogluconate & {$[+]$} \\
\hline Alkaline phosphatase & + & Arbutin & + & 5-Ketogluconate & - \\
\hline Leucine arylamidase & + & Aesculin & + & & \\
\hline
\end{tabular}

tality occurred in control fish, but negative bacteriology, as well as the absence of indicative lesions, excluded any occurrence of Vagococcus salmoninarum.

\section{Vaccination experiment}

Following challenge, survival of the immunized group and of the nonimmunized group of trout evolved in parallel for $57 \mathrm{~d}$. When the experiment was stopped, 26 fish survived in the vaccinated group versus 21 in the controls, and there was no significant difference between the 2 groups $\left(\chi^{2}=\right.$ 0.98).

\section{DISCUSSION}

The diagnosis of Vagococcus salmoninarum was performed on the basis of phenotypic characteristics and confirmed by DNA-DNA hybridization. Both the API 20 STREP and API 50 CHL testing excluded the possibil-
Table 2. Characteristics used to differentiate non-motile, Gram-positive bacteria isolated from salmonids: Vagococcus salmoninarum, Lactococcus garvieae, L. piscium, Australian and South African type of 'Enterococcus', Streptococcus iniae, Carnobacterium piscicola (after a combination of the original descriptions, Schmidtke \& Carson 1994 and the present results). ADH: arginine-dihydrolase; PYR: pyrrolidonyl-arrylamidase; APA: alkaline phosphatase; +: positive; -. negative; d: variable; ND: unreported

\begin{tabular}{|c|c|c|c|c|c|c|}
\hline & V. salm. & L. garv. & L. pisc. & Entero. & S. iniae & C. pisc. \\
\hline Shape & Ovoid & Ovoid & Cocci & Ovoid & Cocci & Rods \\
\hline Haemolysis & $\alpha$ (weak) & $\alpha$ & - & $\alpha$ & $\beta$ & - \\
\hline $\mathrm{ADH}$ & - & + & - & + & + & + \\
\hline Hippurate & $\mathrm{d}^{\mathrm{a}}$ & - & -. & - & - & - \\
\hline PYR & + & + & - & + & + & + \\
\hline $\mathrm{H}_{2} \mathrm{~S}$ & + & - & - & - & - & - \\
\hline \multicolumn{7}{|l|}{ Growth at/in: } \\
\hline $45^{\circ} \mathrm{C}$ & - & + & - & - & - & - \\
\hline $10^{\circ} \mathrm{C}$ & + & + & + & + & d & + \\
\hline $\mathrm{pH} 9.6$ & + & + & - & ND & d & + \\
\hline Bile $40 \%$ & + & + & ND & + & - & - \\
\hline APA & $+t^{b}$ & - & ND & ND & + & ND \\
\hline Starch (acid) & $-{ }^{b}$ & - & $-{ }^{b}$ & - & + & $\mathrm{d}$ \\
\hline L-Arabinose & - & - & + & - & - & - \\
\hline Galactose & - & + & + & + & - & d \\
\hline Glycerol & - & - & - & - & - & + \\
\hline Inulin & - & - & - & - & - & + \\
\hline Lactose & - & $-^{\mathrm{b}}$ & + & - & - & d \\
\hline Mannitol & $-{ }^{b}$ & + & + & + & + & + \\
\hline Melezitose & - & - & + & ND & + & + \\
\hline Melibiose & - & - & + & - & - & d \\
\hline Raffinose & - & - & + & - & - & d \\
\hline Sucrose & + & - & + & + & + & + \\
\hline D-Tagatose & + & ND & - & ND & - & - \\
\hline
\end{tabular}


Table 3. Levels of DNA/DNA homology among the isolated strains and other Gram-positive fish pathogens, as determined by the hydroxyapatite method at $60^{\circ} \mathrm{C}$ (RBR: relative binding ratio; $\Delta T_{\text {mea }}$; difference in melting point between the homologous and heterologous reactions)

\begin{tabular}{|llcc|}
\hline Species & Strain no. & $\begin{array}{c}\text { RBR } \\
(\%)\end{array}$ & $\begin{array}{c}\Delta T_{\text {mie) }} \\
\left({ }^{\circ} \mathrm{C}\right)\end{array}$ \\
\hline Present strains & $\begin{array}{l}\text { 6461-93 probe } \\
\end{array}$ & 2.5 & \\
& $6461-93$ homologue & 100 & \\
& E 4050 & 85.96 & 0.02 \\
& E 4134 & 75.41 & 0.64 \\
& $1412-93$ & 92.62 & 0.65 \\
Vagococcus salmoninarum & $3094-94$ & 94.45 & 0.35 \\
Lactococcus piscium & NCFB 2777 & 81.09 & 0.69 \\
Lactococcus lactis subsp. lactis & NCFB 2778 & 11.92 & 9.75 \\
& NCFB 604 & 36.56 & 8.05 \\
\hline
\end{tabular}

piscicola, and L. piscium could be rejected. Schmidtke \& Carson (1994) concluded that a strong homogeneity exists in phenotypic characteristics of $V$. salmoninarum isolates from distinct geographical origins. This readily permits the diagnosis of the present strains based on routine laboratory criteria.

Most of our isolates' characteristics were in agreement with the amended description of Schmidtke \& Carson (1994), except for hippurate and VogesProskauer. Minor variations were noted in utilisation of sugars, namely sorbose and xylose in which acid production was delayed. Repeating the

ity of any Streptococcus or Enterococcus species known to occur in higher vertebrates. The range of related bacteria recognized in aquatic organisms is still limited to less than 12 species, encompassing some fairly well-defined organisms for which official names have still to be proposed, i.e. the 'Enterococcus' spp. of turbot (Toranzo et al. 1994), of Australia and South Africa salmonids (Carson et al. 1993) and of Singapore Siganidae (Foo et al. 1985), and some $\beta$-haemolytic streptococci from Japan (Kitao et al. 1981) and the USA (Plumb et al. 1974, Baya et al. 1990). Half of these organisms or groups of organisms ( $V$. salmoninarum, Carnobacterium piscicola, Lactococcus garvieae, $L$. piscium, Streptococcus iniae, Australian and African strains of Enterococcus) are likely to affect salmonids. Most of these bacteria are clearly related to warm waters and, in contrast to our strains and L. piscium, can grow above $37^{\circ} \mathrm{C}$. Finally, 4 of these agents are only reported or suspected to occur in Europe. Considering all these criteria and several key characteristics (Table 2), all Streptococcus-Enterococcus species, $C$. tests on different media (CHS for streptococci, CHL for lactobacilli and API STREP) also provided different results for starch, inositol and $\alpha$-methyl-D-glucoside. However, medium and time of incubation may exert some influence on the result of metabolic reactions (Baya et al. 1991).

Experiments in trout demonstrated infection by the strain 119-94, although the mortality was low. The disease was easily initiated by IM injection, and in accordance with field observations its course was chronic. In all cases, the clinical signs and lesions associated with the natural disease were reproduced, and the bacterium was reisolated from dead fish, thus completing Koch postulates. These results, including the severity of the vascular and tissue alterations, and the persistence of the infection in the affected farm, prosalmoninarum as a fish pathogen. The clinical manifestations are likely to depend on external factors and this could suggest an opportunistic agent, although a definitive statement will depend on epidemiological invided sufficient information to demonstrate Vagococcus

Table 4. Cumulative mortality of rainbow trout following experimental infection by different routes, using Vagococcus salmoninarum 119-94

\begin{tabular}{|c|c|c|c|c|c|c|}
\hline \multirow[t]{2}{*}{ Route } & \multirow[t]{2}{*}{$\begin{array}{l}\text { Dose } \\
\text { (cfu) }\end{array}$} & \multirow[t]{2}{*}{$\begin{array}{c}\text { Fish } \\
\text { weight (g) }\end{array}$} & \multirow[t]{2}{*}{$\begin{array}{c}\text { Fish } \\
\text { numbers }\end{array}$} & \multicolumn{3}{|c|}{$\begin{array}{l}\text { Cumulative mortality recorded at } \\
\text { different times post-infection }\end{array}$} \\
\hline & & & & $1 \mathrm{mo}$ & $2 \mathrm{mo}$ & $>2 \mathrm{mo}$ \\
\hline IP injection & $\begin{array}{l}1.8 \times 10^{7} \\
1.8 \times 10^{6}\end{array}$ & $\begin{array}{l}240-360 \\
240-360\end{array}$ & $\begin{array}{l}5 \\
5\end{array}$ & $\begin{array}{l}1 \\
3\end{array}$ & $\begin{array}{l}1 \\
3\end{array}$ & $\begin{array}{l}2 \\
3\end{array}$ \\
\hline IM injection & $\begin{array}{l}1 \times 10^{7} \\
1 \times 10^{6} \\
1 \times 10^{5} \\
1 \times 10^{4}\end{array}$ & $\begin{array}{l}50-90 \\
50-90 \\
50-90 \\
50-90\end{array}$ & $\begin{array}{l}24 \\
20 \\
18 \\
23\end{array}$ & $\begin{array}{l}1 \\
0 \\
1 \\
1\end{array}$ & $\begin{array}{c}3 \\
2 \\
2 \\
11^{\mathrm{a}}\end{array}$ & $\begin{array}{r}4 \\
4 \\
2 \\
12\end{array}$ \\
\hline Immersion & $1.8 \times 10^{7} \mathrm{ml}^{-1}$ & $7-13$ & 100 & 0 & 0 & $4^{b}$ \\
\hline Controls & 0 & $7-13$ & 100 & 0 & 0 & $6^{\mathrm{b}}$ \\
\hline
\end{tabular}


vestigations. As in many other chronic infections, antibiotic treatments carried out in the field did not prove effective, even when susceptibility to several drugs could reasonably be surmised from routine antimicrobial tests. Use of ampicillin and amoxicillin, as well as erythomycin, failed to prevent or decrease trout mortality.

In many aspects, Vagococcus salmoninarum infection expressed the traits of other fish diseases caused by Gram-positive cocci. These usually appear as persistent infections, with recurrent outbreaks starting under particular circumstances and progressing slowly. In some cases, granulomatous inflammation has been described (Miyazaki et al. 1984), but more often the bacteria spread in a septicaemic manner, frequently producing marked exophthalmia and meningoencephalitis (Kitao 1993). Similar signs and lesions were observed here, together with cardiovascular changes of strong and striking intensity. The occurrence of peripheral tissular lesions from which bacteria could not be observed or isolated is noteworthy. 'Aseptic' or poorly colonized lesions have been discussed in turbot enterococcosis (Nieto et al. 1995). This could suggest some distant bacterial toxin, as demonstrated for LaCtococcus garvieae by Kimura \& Kusuda (1979). In humans, streptococcosis are suspected to induce a deposit of circulating antigen-antibody complexes in the wall of skin vessels, resulting in inflammatory lesions (Mims 1976).

Records indicate the bacterium isolated and identified as Vagococcus salmoninarum may have been observed in the same farm in July 1989 and on a second occasion in the absence of clinical signs in May 1992. Moreover, 2 similar strains obtained from the Laboratoire de Pathologie des Animaux Aquatiques of Brest (France) in 1994 appear to be $V$. salmoninarum. Both were isolated from adult rainbow trout from 2 farms in Brittany experiencing low mortality at temperatures between 7 and $10^{\circ} \mathrm{C}$. In one case, pericardial lesions were noticed. Interestingly, there were some differences in carbohydrate reactions (cellobiose, 2-ketogluconate, maltose, sorbitol, Dxylose) between the Brittany and southwest isolates. Although the limited number of samples did not permit any conclusions, perhaps it would be possible to rely on phenotypic markers for further epizootiological purposes.

Schmidtke \& Carson (1994) had incorporated 2 brown trout strains of Vagococcus salmoninarum originating from Norway in their study. The present report confirms that the bacterium is widespread and probably much more common in Europe than previously suspected. Moreover, it may contribute to the fish loss associated with Gram-positive cocci emergence in fish which has recently caused much concern. Its patho- genicity, occurrence as a chronic disease and poor responsiveness to antimicrobial treatments and active immunisation suggest that $V$. salmoninarum could represent an important threat to salmonid farming.

Acknowledgements. The authors wish to express their thanks to Prof. H. Bercovier, whose help was greatly appreciated in the first steps of determination of the organism, to Dr Martine Vigneulle, who supplied the strains isolated in Brittany, to Bernadette Faivre and Raymonde Menguy, for technical assistance in bacteriology and histopathology respectively, and to Dr M. Atkinson, who helped with the English.

\section{LITERATURE CITED}

Austin B, Austin DA (1987) Bacterial fish pathogens. Ellis Horwood, Chichester

Baya AM, Lupiani B, Hetrick FM, Roberson BS, Lukacovic R, May E, Poukish C (1990) Association of Streptococcus sp. with fish mortalities in the Chesapeake Bay and its tributaries. J Fish Dis 13:251-253

Baya AM, Toranzo AE, Lupiani B, Li T, Roberson BS, Hetrick FM (1991) Biochemical and serological characterization of Carnobacterium spp. isolated from farmed and natural populations of striped bass and catfish. Appl Environ Microbiol 57:3114-3120

Brenner DJ, Fanning GR, Rake AV, Johnson KE (1969) Batch procedure for thermal elution of DNA from hydroxyapatite. Anal Biochem 28:447-459

Carson J, Gudkovs N, Austin B (1993) Characteristics of an Enterococcus-like bacterium from Australia and South Africa, pathogenic for rainbow trout, Oncorhynchus mykiss Walbaum. J Fish Dis 16:381-388

Doménech A, Fernández-Garayzábal JF, Pascual C, Garcia JA, Cutuli MT, Moreno MA, Collins MD, Dominguez L (1996) Streptococcosis in cultured turbot, Scophthalmus maximus (L.), associated with Streptococcus parauberis. J Fish Dis 19:33-38

Eldar A, Bejerano Y, Bercovier H (1994) Streptococcus shiloi and Streptococcus difficile: two new streptococcal species causing a meningoencephalitis in fish. Curr Microbiol 28: $139-143$

Eldar A, Frelier PF, Assenta L, Varner PW, Lawhon S, Bercovier H (1995) Streptococcus shiloi, the name for an agent causing septicemic infection in fish, is a junior synonym of Streptococcus iniae. Int J Syst Bacteriol 45:840-842

Eldar A, Ghittino C, Asanta L, Bozzetta E, Goria M, Prearo M, Bercovier H (1996) Enterococcus seriolicida is a junior synonym of Lactococcus garvieae, a causative agent of septicemia and meningoencephalitis in fish. Curr Microbiol 32:85-88

Foo JTW, Ho B, Lam TJ (1985) Mass mortality in Siganus canaliculatus due to streptococcal infection. Aquaculture 49:185-195

Ghittino C, Prearo M (1992) Segnalazionedi Streptococcosi nella trota iridea (Oncorhynchus mykiss) in Italia: nota preliminare. Boll Soc Ital Patol Ittica 8:4-11

Kimura H, Kusuda R (1979) Studies on the pathogenesis of streptococcal infections in cultured yellowtails Seriola spp.: effect of the cell free culture on experimental streptococcal infection. J Fish Dis 2:501-510

Kitao T (1993) Streptococcal infections. In: Inglis V, Roberts RJ, Bromage NR (eds) Bacterial diseases of fish. Blackwell Scientific Publications, Oxford, p 196-210 
Kitao T, Aoki T, Sakoh R (1981) Epizootic caused by $\beta$-haemolytic Streptococcus species in cultured freshwater fish. Fish Páthol 15:301-307

Kusuda R, Kawai K, Salati F, Banner CR, Fryer JL (1991) Enterococcus seriolicida sp. nov., a fish pathogen. Int J Syst Bacteriol 41:406-409

Mims CA (1976) The pathogenesis of infectious diseases Academic Press, London, p 152-156

Miyazaki T, Kubota SS, Kaige N, Miyashita T (1984) A histopathological study of streptococcal disease in tilapia. Fish Pathol 19:167-172

Nieto JM, Devesa S, Quiroga I, Toranzo AE (1995) Pathology of Enterococcus sp. infection in farmed turbot, Scophthalmus maximus L. J Fish Dis 18:21-30

Pier GB, Madin SH (1976) Streptococcus iniae sp. nov., a betahemolytic streptococcus isolated from an Amazon freshwater dolphin, Inia geoffrensis. Int J Syst Bacteriol 26 $545-553$

Plumb JA, Schachte JH, Gaines JL (1974) Streptococcus sp from marine fishes along the Alabama and Northwest Florida coasts of the Gulf of Mexico. Trans Am Fish Soc 103:358-361

Editorial responsibility: David Bruno, Aberdeen, Scotland, UK
Ross AJ, Toth RJ (1974) Lactobacillus-a new fish pathogen? Prog Fish-Cult 36:191

Salati F, Tassi P, Bronzi P (1996) Isolation of an Enterococcuslike bacterium from diseased Adriatic sturgeon, Acipenser naccarii, farmed in Italy. Bull Eur Assoc Fish Pathol 16: $96-100$

Schmidtke LM, Carson J (1994) Characteristics of Vagococcus salmoninarum isolated from diseased salmonid fish. J Appl Bacteriol 77:229--236

Toranzo AE, Devesa S, Heinen P, Riaza A, Núnez S, Barja JL (1994) Streptococcosis in cultured turbot caused by an Enterococcus-like bacterium. Bull Eur Assoc Fish Pathol $14: 19-23$

Wallbanks S, Martinez-Murcia AJ, Fryer JL, Phillips BA, Collins MD (1990) 16S rRNA sequence determination for members of the genus Carnobacterium and related lactic acid bacteria and description of Vagococcus salmoninarum sp. nov. Int $J$ Syst Bacteriol 40:224-230

Williams AM, Fryer JL, Collins MD (1990) Lactococcus piscium sp. nov, a new Lactococcus species from salmonid fishes. FEMS (Fed Eur Micrabiol Soc) Microbiol Lett 68: $109-114$

Manuscript received: November 11, 1996

Revised version accepted: May 22, 1997 